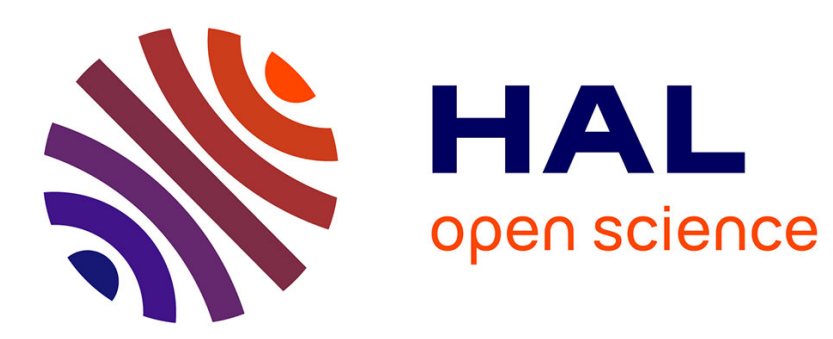

\title{
The past and future of the social sciences. A Schumpeterian theory of scientific development?
}

Stefano Lucarelli, Alfonso Giuliani, Hervé Baron

\section{To cite this version:}

Stefano Lucarelli, Alfonso Giuliani, Hervé Baron. The past and future of the social sciences. A Schumpeterian theory of scientific development?. Cambridge Journal of Economics, 2019, 43 (6), pp.1701-1722. 10.1093/cje/bez001 . hal-02063397

\section{HAL Id: hal-02063397 \\ https: / hal-paris1.archives-ouvertes.fr/hal-02063397}

Submitted on 14 Mar 2019

HAL is a multi-disciplinary open access archive for the deposit and dissemination of scientific research documents, whether they are published or not. The documents may come from teaching and research institutions in France or abroad, or from public or private research centers.
L'archive ouverte pluridisciplinaire HAL, est destinée au dépôt et à la diffusion de documents scientifiques de niveau recherche, publiés ou non, émanant des établissements d'enseignement et de recherche français ou étrangers, des laboratoires publics ou privés. 


\section{The Past and Future of the Social Sciences. A Schumpeterian Theory of Scientific Development?}

Stefano Lucarelli^, Alfonso Giuliani* and Hervé Baron`

FIANL VERSION (19.01.19)

The paper argues that Vergangenheit und Zukunft der Sozialwissenschaften (The Past and Future of the Social Sciences), a contribution not always well understood in the literature, is important to an understanding of Schumpeter's concept of development as applied to the field of the social sciences. To this end, it addresses three key questions. First, can the book be taken as a starting point to reconstruct a Schumpeterian theory of scientific development? Second, is Vergangenheit und Zukunft merely 'a brief outline of what first became the Epochen [der Dogmen- und Methodengeschichte] and finally the History of Economic Analysis', as Elizabeth Boody Schumpeter wrote in her Editor's Introduction (July 1952) to the latter work (p. XXXII), or should it be read as a complement to Epochen and perhaps the History? Third, is the eminent Japanese scholar Shionoya right to claim that Schumpeter's work pursued the ambitious goal of developing a "comprehensive sociology"?

JEL classification: A12, B25, B31, B41.

Keywords: Schumpeter, social sciences, method, scientific development.

-Università degli studi di Bergamo. Email: stefano.lucarelli@unibg.it

*Centre d'Économie de la Sorbonne - (CNRS CES-UMR 8174). Email: alfonso.giuliani@univ-paris1.fr

- Università degli studi dell’Insubria \& Université Paris 1 Panthéon-Sorbonne. Email: hbaron@libero.it

We are grateful to Marco Boffo and to the three anounymous referees for useful suggestions. Special thanks to Nicolò De Vecchi, Andrea Kalajzić for linguistic assistance and to Paul Metcalfe for his final attentive linguistic revision. Finally, we would like to dedicate this paper to the memory of their master, Giorgio Lunghini. The usual disclaimers apply. 


\section{Introduction}

Wassily Leontief began his heartfelt obituary of Joseph Alois Schumpeter with a quotation from a little-known work of Schumpeter's never published in English or in French: 'Investigators existed in all times who stood on a height from which they were able to survey all the land around them rather than a single valley, who not only superficially and from a purely formal point of view recognized the right to exist of the various schools of thought - that amounts to very little - but who had a real understanding of their ideas and felt emotional affinity toward all of them.' (Leontief 1950, p. 103). He continued: 'Schumpeter was one of these exceptional men' (ibid.). The work in question is Vergangenheit und Zukunft der Sozialwissenschaften (The Past and Future of Social Sciences, hereafter VZS), eventually published in 1915 even though Schumpeter began working on it in 1911. An expansion of his farewell lecture at the University of Czernowitz in November 1911, it is not remembered solely as an example of elegant writing. ${ }^{1}$

In the obituary published in the Quarterly Journal of Economics, Haberler (1950) refers to VZS as 'a sort of supplement to his Dogmengeschichte'. The Dogmengeschichte is the Epochen der Dogmenund Methodengeschichte (all references from now on are to the English edition, Economic Doctrine and Method. An Historical Sketch), which had been commissioned by Max Weber for Grundriss der Sozialökonomik (1914). It is interesting to read both works simultaneously, as they appear to complement each other in many important ways. This is not to say that one is susceptible of reduction to the other, however, despite Elisabeth Boody Schumpeter's reference to VZS in the Editor's Introduction (2006[1954] but actually July 1952, p. XXXII) to the History of Economic Analysis as 'a brief outline of what first became the Epochen and finally the History of Economic Analysis'. Machlup (1951, p. 148) also mentions this short work in a note but with a view to explaining Schumpeter's epistemological position, seeing $V Z S$ as an example of the importance Schumpeter attached to the distinction between 'basic assumptions' resting on facts and 'aprioristic, unscientific speculations, little better than scholasticism'. He thus suggests that the farewell lecture of 1911 should be read as a

\footnotetext{
${ }^{1}$ It is worth noting that Vergangenheit und Zukunft der Sozialwissenschaften was available only in German and Japanese for a very long time. There is now a good Italian edition by Adelino Zanini with notes and a brief editor's introduction offering some very interesting insights. Attention should also be drawn to the short note on the translation, where Zanini discusses the difficulties to be encountered by the reader in grappling with Schumpeter's typically obscure turns of phrase. Moreover, Schumpeter uses very complex and academic language in this particular essay, deliberately adopting the "current rhetoric" of the day, which makes it hard to convey all the nuances of his phrasing, especially in English.
} 
continuation of the methodological analyses found in Schumpeter's first book, Das Wesen und der Hauptinhalt der theoretischen Nationalökonomie (1908). The readings of Machlup and Elisabeth Boody Schumpeter thus appear to support the view that Schumpeter's writing on the social sciences is no more than a preamble to his work on economic theory. One of the aims pursued here is to challenge this interpretation.

It may therefore be worth considering the question of whether Schumpeter's VZS is a preamble that highlights significant differences, both in the method and in the evolution of analytical history, between economic theory and the other social sciences. This alone would, in our opinion, stimulate the curiosity of any scholar wishing to understand the exact function in Schumpeter's work of his reflections on the past and future of the social sciences. These were developed from 1911 to the Christmas of 1914, when Schumpeter finished the book, an extremely eventful period in terms both of theoretical developments in Austrian and German universities and of Schumpeter's professional and intellectual life.

Echoes of the Methodenstreit were indeed still reverberating between 1911 and 1914 in the debate on the value neutrality of the social sciences, where Max Weber respectfully but firmly disagreed with Gustav von Schmoller. This issue was part of the theoretical context in which $V Z S$ was produced, and it is therefore our belief that the book is bound up with the debate as well as with some different ideas that Schumpeter developed in other writings of the period. It was in fact between 1911 and 1912 that Schumpeter published his most important book, Theorie der wirtschaftlichen Entwicklung (The Theory of Economic Development, henceforth: TED). He then defended the theory of the interest rate put forward in it against stringent criticism from his mentor Böhm-Bawerk the following year and went on to publish the above-mentioned Economic Doctrine and Method. An Historical Sketch in 1914. As regards teaching, in addition to his course on economic theory during the winter of 1910-11, he delivered a series of lectures on State and Society, an issue subsequently developed through a theory of social classes. Finally, the period 1911-14 saw the twilight of the Austro-Hungarian Empire, the gradual disappearance of the world in which Schumpeter's theoretical framework and mind were shaped.

To summarise, while it is true that the 1915 essay is in many respects a piece of occasional writing, we contend that its importance should not be underestimated for more than one reason:

1. VZS presents an evolutionary framework of the social science complementary to the analysis of the evolution of the economic structure put forward in The Theory of Economic Development. 
2. VZS helps us to understand the role played by metaphysics, understood as a dogmatic perspective, within Schumpeterian thought.

3. The fact that by Soziologisierung Schumpeter means the scientific method characteristic of different disciplines that address social phenomena.

This study will therefore address the following research questions:

- First, can the book be taken as a starting point to reconstruct a Schumpeterian theory of scientific development?

- Second, is VZS merely a brief outline of what first became Economic Doctrine and Method. An Historical Sketch and finally the History of Economic Analysis or should it be read, rather, as a complement to Economic Doctrine and Method and perhaps the History? Furthermore, can VZS help us to understand the role played by metaphysics, understood as a dogmatic perspective, within Schumpeterian thought?

- Third, is the eminent Japanese scholar Shionoya right to claim that Schumpeter's work pursued the ambitious goal of developing a "comprehensive sociology"?

With a view to presenting these reasons correctly, the paper is organised as follows. Due to the lack of an English edition, section 2 provides a critical overview of the arguments put forward in VZS. Section 3 reconstructs the Schumpeterian theory of scientific development presented in VZS and argues that the work should not be regarded merely as a brief introduction to History of Economic Analysis but instead as a kind of complement to Economic Doctrine and Method, and indeed as a work with important peculiarities of its own with respect to the History. Section 4 clarifies the distinctive features of VZS and points out some misunderstandings arising out of its not entirely accurate interpretation, in particular the meaning of the term Soziologisierung. Section 5 puts forward some final considerations and conclusions.

\section{VZS as a theory of scientific development}

\subsection{From the emergence of social sciences to the 18th century}

VZS is an organic work divided into five parts. ${ }^{2}$ The first and shortest part (pp. 3-9) constitutes a sort of introduction in which the author primarily states his aim of showing how the functioning of the

\footnotetext{
${ }^{2}$ One of the referees has asked for deeper clarification of the differences between parts $1 \& 2$ of $V Z S$ and the first part of Economic doctrine and method. An historical sketch. While the arguments developed are in fact complementary, there are
} 
social sciences is connected with their past and where it may lead them in the future. This is obviously a difficult task, above all because there is not just one social science but a number of different social sciences whose boundaries overlap in various ways. ${ }^{3}$ Schumpeter's argument is developed chronologically up to the third part. While Homer and Herodotus are mentioned, the reconstruction actually starts from the Middle Ages, an era in which the social sciences did not exist. The forms of knowledge typical of that period, such as theology and jurisprudence, were not in fact concerned with social issues or the human psyche but rather dogmatic disciplines designed to confirm a revealed system regarded as forever valid. It is thus immediately clear what cannot be regarded as science, namely dogmatic knowledge. ${ }^{4}$

Schumpeter describes the Renaissance as an era during which scientific thinking managed to emerge despite the continuing failure to accord centrality to social issues: 'No one yet looked beneath the veil of religious zeal that enveloped the wars of religion, no one saw what lay concealed beneath gigantic social needs.' 5

The second part addresses the emergence of the concept of social phenomena in scientific thinking (pp. 8-59). According to Schumpeter, the origin of the social sciences dates back to the 18th century, when the end of the religious wars and the birth of the Industrial Revolution led to an upheaval affecting the entire political sphere. In this context, the ancient knowledge of theology and jurisprudence was called into question by new issues put forward by scholars of a new type. The emergence of the social sciences was not linear, however, and the various debates arising did not in themselves entail the creation of new knowledge characterised by the modern scientific method. In the slow process whereby the social sciences broke free of medieval knowledge and the Renaissance tradition, what catches Schumpeter's attention is primarily the role played by natural theology: '[Many of these new scholars] did not make a clean break with theology but dragged part of it along with them.

important differences, in that the essay of 1914 regards the development of economics as a science and no reference whatsoever is made to the other social sciences. Moreover, the analysis is confined to the influence of moral philosophy on Adam Smith's work and the impact on the formation of classical economics of the concrete problems of public intervention during the 16 th, 17 th and 18 th centuries.

3 See Schumpeter 2014[1915], pp. 3-4. From now on, all quotations from Vergangenheit und Zukunft der Sozialwissenschaften (and from Das Wesen und der Hauptinhalt der theoretischen Nationalökonomie) are to be understood as our tentative translations. While endeavouring to make the text as accessible as possible to the English reader, we have also attached importance to following the original German version syntactically wherever possible.

${ }^{4}$ It should be noted that Schumpeter also puts forward a brief but interesting observation on the actual use of Platonic and Aristotelian philosophy by medieval theologians and jurists, which he regards as wholly pretentious and making no addition whatsoever to knowledge. See the footnote in Schumpeter 2014[1915], p. 7.

5 Original: 'Niemand blickte noch unter den Schleier der religiösen Begeisterung, der die Religionskriege umhüllte, niemand sah, was an gewaltigen sozialen Notwendigkeiten darunter verbogen lag'. Schumpeter 2014[1915], pp. 8-9. 
The separation did finally come, but first there was 'natural theology'. [...] This was not a science of the social functions and manifestations of religion [...] but rather a discussion of the substance of fundamental tenets/dogmas and an attempt to prove or refute them logically. [...] [S] uch discussions [were] prior to scientific investigation of the psychological and sociological facts of religious life. ${ }^{6}$

In order to clarify the complex relationship between theology and science, it is worth quoting the following passage as well at some length: '[...] I would say that the assumption or realization that all events are governed by laws, on which all science rests, comes about in the following stages. It is understood first as the extramundane effect of divine will, second as the expression of something mental identical to the world, third as the manifestation of 'forces' that are natural but existing as particular realities, and finally as the empirically given relationship between phenomena dependent on one another. As regards content, the insights of science can be the same no matter what vision may be adopted. The 18th century had already completed the fourth stage in particular branches. It essentially started from the first and the overwhelming majority of thinkers stopped between the second and third. ${ }^{7}$ Schumpeter thus appears to be asserting the need to take into account the influences that

\footnotetext{
${ }^{6}$ Original: '[Viele jener neuen Gelehrten] schieden nicht einfach von der Theologie, sondern zogen ein Stück mit sich fort. Schließlich kam es zum Scheiden, aber vorher noch zur „natürlichen Theologie“. [...] Und sie war nicht [...] Lehre von den sozialen Funktionen und Erscheinungsformen der Religion [...] sondern eine Diskussion des Wahrheitsgehaltes der fundamentalen Glaubenssätze, ein Versuch, diese Glaubenssätze logisch zu beweisen oder zu widerlegen. [...] [S]olche Diskussionen Vorläufer waren für jene wissenschaftliche Untersuchung der psychologischen und soziologischen Tatsachen des religiösen Lebens.' Schumpeter 2014[1915], p. 18.

It is also worth pointing out that the attention focused on theology in this concise but extremely dense passage is by no means marginal. While this approach may unquestionably appear at a first sight to be influenced by Weber's famous inquiry into the relationship between religion and society, closer examination reveals such influence to be wholly absent. Schumpeter focuses in actual fact on a typical "concept" of 18th-century theology, namely deism, which is able to provide "congenial ground" for social sciences. Quite simply, this reference to the religious dimension does not rely on ethics and does not serve to identify the spiritual conditions for the rise of the capitalist mode of production. The two approaches do not overlap and there are very significant differences with regard to Max Weber's research. Schumpeter regards deism as an intermediate stage between the belief in revelation of previous generations of researchers and the different types of materialism that developed in the 19th century (see Schumpeter 2014[1915], p. 20). He is interested, as we shall see, in a line of reasoning aimed at highlighting the evolutionary logic of the social sciences.

${ }^{7}$ Original: '[...ich] würde [...] sagen, daß die Annahme oder Erkenntnis der Gesetzmäßigkeit alles Geschehens, auf der alle Wissenschaft beruht, sich in den folgenden Etappen durchringt: Zuerst wird sie verstanden als Wirkung außerweltlichen Götterwillens, dann als Äußerung eines mit der Welt identischen geistigen Etwas, dann als Ausdruck irgendwelcher natürlicher, aber als besonderer Realitäten existierender „Kräfte“, endlich als erfahrungsgemäß gegebene Beziehung zwischen den sich gegenseitig bedingenden Erscheinungen. Inhaltlich können die Erkenntnisse der Wissenschaft dieselben sein, welcher Anschauung man auch huldigen mag. Das 18. Jahrhundert vollendete in einzelnen Ausläufern schon die vierte Etappe. Ausgegangen ist es im Wesen noch von der ersten. Und die Masse der Denker hält überwiegend zwischen der zweiten und dritten.' Schumpeter 2014[1915], p. 23. It should be noted that the phrase 'dann als Ausdruck irgendwelcher natürlicher, aber als besonderer Realitäten existierender „Kräfte“" is very difficult to understand and therefore to translate, so that what is put forward at that point is more of an interpretation than a literal translation like 'as the expression of some natural "forces" but existing as characteristic realities'. For Schumpeter's views on the legitimacy of employing an interpretation of a theory, see De Vecchi 1995, pp. xv-xvi.
} 
dogmatic attitudes cyclically exert over scientists. He is indeed convinced that dogmatics is first and foremost a peculiar characteristic of metaphysics and thus - we might add - of a large part of the Western philosophical tradition. In other words, metaphysics is nothing other than one of the unwelcome guests interfering with the work of social scientists. ${ }^{8}$ Schumpeter would prefer to eliminate it because, according to an idea that is still widely held today, metaphysics is detrimental to the work of scientists who study social reality. ${ }^{9}$

Both rational psychology and empirical psychology emerge from the critical analysis of metaphysics. It is these trails of research blazed in the German academic world that lead, in Schumpeter's view, to the theory of motivation, subsequently developed above all in an individualistic perspective in the Anglo-Saxon world.

It should also be noted that Schumpeter does not reduce psychology to hedonistic egoism, as Bentham's utilitarianism does. Utilitarianism is unmistakably described as an extremely reductive way of conceiving behavioural motives. ${ }^{10}$ Both egoism and the principle of sociality, regarded by Schumpeter as pivotal to the development of law, are principles that scholars claim to base on experience.

Crucial emphasis on experience is the lowest common denominator of different areas of knowledge emerging in the course of the 18th century. Schumpeter briefly examines these areas: psychology (pp. 26-31), logic (p. 31), aesthetics (pp. 31-32), ethics (pp. 32-37), law (pp. 37-48), political economy (pp. 48-50) and historical investigation (pp. 50-57). It will suffice for our purposes to consider his observations on law and political economy.

The pages devoted to law, or natural law to be more precise, are of great importance. The history of natural law serves the function of distinguishing between knowledge concerning the nature of legal

\footnotetext{
${ }^{8}$ Another, in Vergangenheit und Zukunft, is perhaps the "political dimension" of theories, as we shall show (see footnote 20).

9 The rejection of metaphysics in economics is demostrated by the fact that it is presented to students as a series of propositions considered self-evident and corresponding to general laws. These propositions have to be tested empirically. See for example Kreps 1990, p. 7: 'Having set out the basic categories of microeconomic theory [...], we come to the question: What do we intend to get out the theory? The simple answer is a better understanding of economic activity and outcomes. [...] What constitutes better understandings? Put differently, how does one know when one has learned something from an exercise in microeconomic theory? The standard acid test is that the theory should be: (a) testable and (b) tested empirically either in the real world or in the lab'. While all this is apparently grounded on Popperian falsifiability, metaphysics is simply regarded as "non-science" in the references to Popper made by economists (e.g. Blaug, 2009[1980]). In other words, the heuristic function of metaphysics (as the source of heuristic principles subsequently transformed into scientific theories) recognised by Popper himself in chapter 1, paragraph 4, pp. 10-16 of The Logic of Scientific Discovery 2005[1935], is completely overlooked.
}

${ }^{10}$ See Schumpeter 2014[1915], pp. 29-31. 
phenomena and aspirations to ideal systems. This distinction thus makes it possible to identify the differences between research programs based on factual reality and dogmatic or metaphysical approaches, recalling once again Schumpeter's negative view of metaphysics. It is out of this divergence that the different social sciences originated. According to Schumpeter's vivid expression: 'What the Nile is to Egypt, natural law was to the intellectual life of the social sciences in the 18th century." 11 It is worth noting that by natural law he means positive science characterised by the inductive method, which is in turn grounded on the awareness that law grew out of social needs rather than abstract speculation. Schumpeter outlines the history of a discipline that struggles to evolve because it finds it hard to jettison the idea that it is possible to identify a moral law valid for all historical eras and all places. According to Schumpeter, the most important outcome of this difficult process was the sociology of law, a discipline that came into being only after a series of misunderstandings such as to justify a distorted image of natural law as 'a limited, quite trivial and unscientific mixture of Enlightenment biases [and] dull scholastic dogmas'. ${ }^{12}$

It is at this stage in the argument that Schumpeter offers contemporary economists a thoughtprovoking opportunity with the idea of political economy as born out of natural law. Like natural law, political economy deals with the reality of facts but also faces the same risks. It claims to discover laws that are valid in all times and places, i.e. an economic system that is consistent with human nature. ${ }^{13}$ As Schumpeter points out, however, historical materials become part of scientific thinking only if: 1) they become a field of application of the outcomes of social sciences: 2) they can highlight regularities that lead to the framing of more or less general scientific laws. ${ }^{14}$

\subsection{The 19th century and beyond}

The third part of VZS (pp. 59-81) seeks to show the hampering factors that prevented many possible achievements from being made during the 19th century, the first of these being the 18th century "worldview" (Geistesrichtung) of Enlightenment philosophy and political liberalism. The identification of this tendency leads Schumpeter to formulate a "diffusion model" of ideas capable of bringing about

${ }^{11}$ Original: 'Was der Nil für Ägypten ist, das war das Naturrecht im 18. Jahrhundert für das sozialwissenschaftliche Geistesleben.' Schumpeter 2014[1915], p. 38.

${ }^{12}$ Original: 'ein enges, banales, unwissenschaftliches Gemenge von Aufklärungsvorurteilen, von dürren, scholastischen Dogmen'. Schumpeter 2014[1915], p. 41.

${ }^{13}$ See Schumpeter 2014[1915], p. 50. It should be noted that this is a dogma that still appears to characterise economic orthodoxy.

${ }^{14}$ See Schumpeter 2014[1915], pp. 51-52. 
a change in the social balance: 'New ideas and schools of thought first originate in the narrowest circles. There they acquire their prophets and militants, and from there, in the event of success, a great cloud of dust rises that attracts the attention of other circles and conceals for a long time how vanishingly small the group of disciples really is. Other circles absorb only the battle cries at first and otherwise remain comfortably set in their old ways. If further progress is made, these battle cries come into contact with sensitive points as though in bloody earnest. It then becomes apparent how little of the new thought has actually been absorbed and a situation arises that is wholly analagous to an economic crisis. ${ }^{\text {}}{ }^{2}$ With his highly idiosyncratic language full of metaphors relating to military life, Schumpeter describes a complex evolutionary process (the absorption of new ideas) that can be simplified as follows: new ideas are transmitted and thereby lose their original meaning, thus giving rise to misunderstandings that lead to real change in the social sciences and make crises possible at the same time. This dynamics is characterised by further misunderstandings of ideas as they gradually spread, thus resulting in fragile institutional structures that legitimise a counter-revolution. One kind of counter-revolution characterising the transition from the 18th to the 19th century is demonstrated by Romanticism's strong opposition to Utilitarianism. Schumpeter thus recalls Carlyle and describes him as a genius who is blind before science. He detects the same blindness in a scientist who has nothing to do with Romanticism, namely Comte, regarded as a victim of the belief that nothing good had been done in the past in the field of social sciences. Schumpeter's criticism does not, however, appear to be primarily aimed at these two scholars but rather at the "dogmas" of the Historical School. ${ }^{16}$ While his disdain for this school is somewhat toned down in these pages and his views are not as irreverent as in Das Wesen und der Hauptinhalt der theoretischen Nationalökonomie, ${ }^{17}$ he does show how its critical

\footnotetext{
${ }^{15}$ Original: 'Neue Ideen und neue Richtungen entstehen zunächst in engsten Kreisen. Da gewinnen sie ihre Propheten und Kämpfer, und von da aus entsteht im Falle des Erfolgs die große Staubwolke, die den Blick weiterer Kreise anzieht und lange darüber täuscht, wie verschwindend klein eigentlich die Schar der Jünger ist. Weitere Kreise absorbieren zunächst nur Schlagworte und bleiben sonst ruhig in den alten Bahnen. Soll es dann weitergehen, rühren diese Schlagworte an empfindliche Stellen und sieht es so aus, wie wenn sie blutiger Ernst werden sollten, dann zeigt es sich, wie wenig das Neue noch assimiliert ist und es entsteht eine Situation, die völlig analog einer Wirtschaftskrise ist.' Schumpeter 2014[1915], p. 64. For the translation of "Schlagworte" as "battle cries", see below note 27.

${ }^{16}$ See Schumpeter 2014[1915], pp. 75-81.

${ }^{17}$ Even if Schumpeter did apply a sort of "Monroe doctrine of economics" in writing his first book, as claimed by Kesting (2006, p. 390), this does not mean that he considered the Historical School relevant from a theoretical standpoint. See for example Schumpeter 1908, p. 125: 'The Historical School tells us nothing new when it points out that every phenomenon is a result of multifarious influences and complicated processes' (emphasis added). This is our translation of the following passage: 'Die historische Schule sagt uns nichts Neues, wenn sie darauf hinweist, daß jede Erscheinung ein Resultat vielgestaltiger Einflüsse, komplizierter Prozesse ist.'

Once in Czernowitz, however, Schumpeter seems far away from the views expressed in his book of 1908, in particular the idea that economic theory can develop only by severing all links with the other social sciences and especially history.
} 
stance towards natural law and economic theory is politically motivated by opposition to legislative reforms based on liberal economic policies. Schumpeter points out that this attitude involves a mistaken idea of the past and results moreover in the loss of important scientific knowledge and precious time.

The fourth part (pp. 81-108) is devoted to the present situation in the social sciences. Schumpeter tries to identify the negative effects of dogmas on the work of social scientists in order to formulate a theory of the development of the social sciences, pointing out that 'unwittingly and against their will, all the 19th-century schools of thought continued along the paths already taken, and so the continuity they wished to disrupt was preserved by iron-clad necessities'. Finally and most crucially, Schumpeter insists that 'all of the work of the 19th century took the same course as that of [previous] centuries' ${ }^{18}$ Basically the same view is expressed by Schumpeter with respect to Methodenstreit in Economic Doctrine and Method. An Historical Sketch: disputes between schools often make little sense and result only in a waste of time. ${ }^{19}$

While buried and forgotten viewpoints can arise again in the evolution of the social sciences, according to Schumpeter, this does not directly depend on the political dimension ${ }^{20}$ or on the power relations between different schools of thought. He goes beyond this interpretation in the following assertion: 'It might be well said in general that whenever science [...] is associated with a partisan political or philosophical position, it is exposed to non-scientific attack and necessarily caught up to a greater or lesser extent in the fate of the politics or philosophy in question. ${ }^{21}$ Therefore, like metaphysics, the political dimension also causes interference that is potentially disastrous for any scientific debate.

See Swedberg 1991, chapter 2. See Shionoya 1991 for a meticulous reconstruction of the connections between Schumpeter and the Historical School. About the importance of Czernowitz's experience in Schumpeter's thought see also McCraw 2007.

${ }^{18}$ Original: 'alle [...] Schulen und Richtungen des 19. Jahrhunderts, gegen ihren Willen, ohne ihr Wissen, haben in den eingeschlagenen Bahnen [weitergearbeitet], daß die Kontinuität, die sie zerreißen wollten, gewahrt wurde von ehernen Notwendigkeiten', and 'daß alle Arbeit des 19. Jahrhunderts in derselben Linie liegt wie die der [vorherigen] Jahrhunderte'. Schumpeter 2014[1915], p. 85. This point will be further developed below in discussing the concept of the "logic of things". ${ }^{19}$ See Schumpeter 1954[1914], especially chapter IV, pp. $167 \mathrm{ff}$.

${ }^{20}$ In this context, political dimension means both the influence that a partisan political position can have on research in the social sciences and the evaluation of such research on the part of policy makers.

${ }^{21}$ Original: 'können wohl allgemein sagen, daß wenn immer Wissenschaft [...] mit politischer oder philosophischer Parteistellung assoziiert wird, sie Angriffen außerwissenschaftlichen Charakters ausgesetzt sein und in das Schicksal der betreffenden Politik oder Philosophie mehr oder weniger hineingezogen werden muß.' Schumpeter 2014[1915], p. 95. This passage can help to understand that Schumpeter's thought on the evolution of the social sciences is characterised by a sort of "impolitical radicalism". See Zanini (2008), especially chapter 3. 
This said, Schumpeter identifies the following among the endogenous variables that influence scientific evolution: 1) shifts of mood or opinion in social groups; 2) the diversity of social groups and individuals that act as leaders in different periods; 3 ) the narrow focus of individual researchers; 4) the ability of research groups to disseminate their work and cooperate; 5) the vanity and lack of generosity that cause researchers to seek to impose their views and destroy any others. ${ }^{22}$

Nevertheless, there is a sort of Logik der Dinge or "logic of things" 23 that implies the actual coexistence of factors of discontinuity and factors of continuity. This logic produces a line of development that is certainly not straight but ultimately proves consistent. In general, any attempt to destroy the research of scientists who belong to different schools generates an opposite reaction. It is therefore possible to identify if not a law, at least a logic of development that may appear paradoxical only at first sight. As Schumpeter argues: 'the less consistent a unified and persistently pursued work programme may be, the more consistent will the development of the retrospective overview appear in the long term'. 24

In the fifth and last part (pp. 109-136), Schumpeter seeks to apply the "logic of things" outlined above to the future development of the social sciences. After highlighting the problems that arise out of naive dilettantism, he recalls the debate on the value-neutrality of the social sciences, which involved Max Weber among others. He restates the boundaries within which the work of social scientists must be kept, avoiding any invasion of the normative sphere of "ought" (Sollen), and indeed warns us that 'an exclusive or predominant focus on practical issues of the day threatens to overwhelm interest in the work from a purely scientific viewpoint and thus endanger the progress of science. Practical questions [...] are to science as the primitive search for food is to production: the objective is pursued directly in both cases without first creating the necessary tools through prolonged work. It is, however, only this long, disinterested work with no intended practical implementation that helps science to go forward. ${ }^{25}$

\footnotetext{
22 See Schumpeter 2014[1915], pp. 94-99.

${ }^{23}$ See Schumpeter 2014[1915], p. 102.

${ }^{24}$ Original: 'je weniger konsequent jemals ein einheitliches Arbeitsprogramm dauernd festgehalten werden kann, umso konsequenter wird sich die Entwicklung der retrospektiven Überschau über große Zeiträume darstellen'. Schumpeter 2014[1915], p. 102.

${ }^{25}$ Original: 'die ausschließliche oder vorwiegende Beschäftigung mit praktischen Tagesfragen droht das Interesse an der Arbeit nach lediglich wissenschaftlichen Gesichtspunkten zu erdrücken und damit den Fortschritt der Wissenschaft zu gefährden. Praktische Fragen [...] sind [...] für die Wissenschaft das, was in der Produktion die primitive Nahrungssuche ist: man geht in beiden Fällen direkt auf sein Ziel los, ohne erst in langer Arbeit die Werkzeuge dazu zu schafften. Und doch ist es allein diese lange, desinteressierte, an keine praktische Anwendung denkende Arbeit, die der Wissenschaft weiterhilft.' Schumpeter 2014[1915], pp. 115-116.
} 
The closing pages of $V Z S$ stress that while every social science, and especially economics, develops into many schools and theories, the tools used in each different field aim at just one scientific method that is always the same. Schumpeter seems to be spurred on by great hopes for the culture of his time, which he regards as capable of explaining many problems by virtue of specialisation. He appears confident that the social sciences will go on developing and that even some results of his own era will eventually be considered incorrect. In any case, the scholars of the future will continue the work of today. ${ }^{26}$

To sum up, the structure of $V Z S$ shows that its aim is to put forward a theory of scientific development: from the analysis of the differences between science and dogmatic knowledge that characterises the first chapter to the outline of the future of social sciences that concludes the discourse. In this argument, the descriptions of the historical process leading from natural theology to natural law in the second chapter and the features of the Enlightenment philosophy and political liberalism in the third are the primary sections for an understanding of the present situation in the social sciences. The "diffusion model of ideas" can be introduced straight after the identification of the Geistesrichtung or world view of the 18th century. It is, however, the endogenous shocks represented by the interference of metaphysics and, more recently, the political dimension that play a key part in Schumpeter's logic of development, as we shall see in the following section.

\section{Placing VZS in its correct context: theories of development, metaphysics and ideology}

We shall divide the argument developed in this third paragraph into two parts, mutually interconnected: the first part concerns the comparison between the structure of the theory of development present in $V Z S$ and the one present in TED; the second part explores in what sense metaphysics plays a key role in the logic of social sciences development, as presented in $V Z S$, and accounts for the change of perspective, concerning this topic, of subsequent works.

\subsection{Theories of development}

After providing a precise idea of the contents of $V Z S$, let us now take the next step. Examination of Schumpeter's theory of the evolution of the social sciences makes it possible to discern some parallels with his theory of economic development. First, there is a situation, similar to the "circular flow"

\footnotetext{
${ }^{26}$ Schumpeter 2014[1915], pp. 135-136.
} 
(Kreislauf) of the economy, in which the social sciences rest solely on a "worldview" (Geistesrichtung). This was the framework at the end of the 18th century, according to Schumpeter. Moreover, just as the circular flow is periodically interrupted by the appearance of the entrepreneurinnovator in the economic field, a widespread reaction to a given worldview sometimes arises in the scientific sphere. Furthermore, earlier knowledge is called into question by scholars of a new type, just as, in the economic field, those who introduce an innovative new product are not those who supply the existing products. Since innovators in the social sciences are few, however, at the very beginning the new tendencies arise only in narrow circles (just as capitalist development is prompted by few innovators). Subsequently, just as the innovative entrepreneurs are followed by numerous imitators, new scientific ideas attract the attention of other circles and eventually gain their acceptance. More precisely, Schumpeter argues that these new circles only take up the new "battle cries" (Schlagworte) ${ }^{27}$ while remaining essentially faithful to the old ways. Finally, just as the arrival of imitators erodes the entrepreneurs' profit and steers the economic system towards a new situation of circular flow through the deflation of a boom, it emerges when the new battle cries come into contact with sensitive points (empfindliche Stellen) that the new conceptions have been assimilated only to a very limited extent. The situation is therefore one in which the dissemination of new theories is ultimately characterised by the absence of a real scientific approach. As Schumpeter points out, this is very similar to an economic crisis, ${ }^{28}$ which essentially consists in difficulty in the absorption of production leading to panic and hence to collapse. ${ }^{29}$

As a corollary of this first comparison, it is important to underline that, both in $V Z S$ and TED, Schumpeter describes dynamics, giving relevance to the concept of "evolution" understood as a change generated endogenously by the system.

In addition to the similarities, however, there are also differences to be noted that are in fact no less striking, and such differences have two distinct meanings of the concept of evolutionary (endogenous) change. The first, present in $V Z S$, with a more positivistic flavour and anticipating, in some ways, the Vienna Circle Manifesto, the second, present in TED, influenced by the attempt to construct a theoretic

27 Schlagwort is a compound made up of Schlag, meaning "shock", and Wort, meaning "word". It is not used by Schumpeter in the sense of a scientific or fundamental "keyword". It could be translated as "slogan" but in this specific context it refers to a collective reaction of full and uncritical agreement with the new ideas, and can therefore be correctly translated as "battle cry".

${ }^{28}$ On the similarities between economic and scientific evolution, see Schumpeter 1961[1926], especially chapter 6, pp. $212-$ 255, and Schumpeter 2014[1915], p. 64.

${ }^{29}$ See Schumpeter 2014[1915], pp. 64-65. 
model of the process of economic change in time, i.e. to answer the question how the economic system generates the forces which incessantly transforms it. The concept of evolution as endogenous change, in fact, presupposes, in Schumpeter's thought, that, during the process of change, some fundamental characteristics of the system structure are maintained and that, at the same time, transformations emerge which, at a certain point, are so significant as to involve a new system structure. This new configuration has temporary stability. In this sense, it can be argued that the evolutionary change is the result of the iteration between continuity and discontinuity. While the emphasis in TED is on the moment of discontinuity, the interruption of the circular flow, ${ }^{30}$ which is what really matters, the opposite occurs in $V Z S$, where the stress is on continuity, what Schumpeter calls the "logic of things" (Logik der Dinge).

It is worth stressing that this structural invariance, typical of the scientific method and illustrated in $V Z S$, is not present in TED precisely because the logic that guides entrepreneurship and innovation, unlike the scientific method, cannot be fixed on a permanent basis over time.

\begin{tabular}{|l|l|}
\hline $\begin{array}{l}\text { Evolution of the social sciences } \\
\text { (stress on continuity) }\end{array}$ & $\begin{array}{l}\text { Evolution of economic structure } \\
\text { (stress on discontinuity) }\end{array}$ \\
\hline $\begin{array}{l}\text { 1) The social sciences rest on a single world } \\
\text { view (Geistesrichtung). }\end{array}$ & $\begin{array}{l}\text { 1) The economy is in a state of circular flow } \\
\text { (Kreislauf). }\end{array}$ \\
\hline $\begin{array}{l}\text { 2) Earlier knowledge is called into question by } \\
\text { scholars of a new type. Yet, many of these new } \\
\text { scholars have not made a clean break with } \\
\text { previous ideas. }\end{array}$ & $\begin{array}{l}\text { 2) Typically the introducers of the innovative } \\
\text { new product are not the same suppliers of the } \\
\text { existing products (the owners of the mail } \\
\text { coaches were not the builders of railways). }\end{array}$ \\
\hline $\begin{array}{l}\text { 3) New tendencies arise only in narrow circles } \\
\text { during the first stage. }\end{array}$ & $\begin{array}{l}\text { 3) Capitalist development is prompted by few } \\
\text { innovators. }\end{array}$ \\
\hline $\begin{array}{l}\text { 4) New scientific ideas attract the attention of } \\
\text { other circles, which eventually accept them but } \\
\text { actually take up only the new "battle cries" }\end{array}$ & $\begin{array}{l}\text { 4) Innovations cause a change in traditional } \\
\text { behaviour and give rise to numerous imitators. }\end{array}$ \\
\hline
\end{tabular}

\footnotetext{
${ }^{30}$ See Schumpeter 2011[1911], pp. 79-154, i.e. the English translation of the first edition of Theorie der wirtschaftlichen Entwicklung (II chapter), where the stress on discontinuity is even stronger than in the subsequent edition(s). See also Shionoya 2004, p. 337 (our emphasis): 'In sharp contrast with economic statics, Schumpeter constructed a dynamics or a theory of economic development [...]. He defined economic development by reference to three elements: its cause (innovation), its carrier (entrepreneurship), and its means (bank credit). Economic development is the destruction of circular flow $[\ldots]$...

In this connection, see also da Graça Moura 2015, pp. 1130-1131 and 1132-1133.
} 


\section{(Schlagworte)}

5) It emerges on contact between the new battle cries and sensitive points how little the new elements have been assimilated (Logik der Dinge), thus leading to a situation similar to an economic crisis.

5) The numerous imitators steer the economic system towards a new Kreislauf through a deflationary spiral. This situation lasts only until the appearance of a new swarm of innovators.

Table 1. Comparison of scientific and economic evolution

It may thus appear that a crucial contradiction between continuity and discontinuity can be discerned in Schumpeter's reflection on the social sciences. On the one hand, he clearly draws attention to the phenomenon of grouping and the existence of opposing schools. ${ }^{31}$ On the other, however, he suggests that there is no real difference in principles and methods. There are in fact two levels involved here, one regarding conflict between schools of thought and the other science in the true sense. What really counts is proper scientific work free from metaphysical - and possibly political - bias. Though conflicts and disputes apparently predominate in the scientific world, he believes that it is possible at a deeper level to attain a development of various (social) sciences consistent with the objective problems to be solved. Schumpeter's goal, namely penetrating analysis of the basic elements of the social world, emerges very clearly here. An evocative observation put forward by Shionoya, albeit in a different perspective, ${ }^{32}$ can be used to stress this point still further: 'Although the process of scientific activity is in a tangle like a tropical forest, the history of science can be written as if it was a logically consistent architecture' (Shionoya 2009, p. 591).

The question can nonetheless be asked of how it is possible to grasp this contradiction between continuity and discontinuity within the framework provided by the young Schumpeter. In order to answer, it is necessary to discuss Schumpeter's concept of science. As convincingly argued by da Graça Moura (see da Graça Moura 2002, 2003; the question is taken up again in da Graça Moura 2015), his view of the structure of scientific theories presupposes the world as a closed system, meaning 'a system characterized by universal constant conjunctions of events of the form 'whenever event $x$, then event $y$ ''(da Graça Moura 2003, p. 280), as against open systems, 'in which such conjunctions do not typically [hold]' (ibidem). Open systems are therefore ones in which radically new

\footnotetext{
${ }^{31}$ See Schumpeter 2014[1915], pp. 79-81, where he gives the example of the historical school of economics vs. the liberal school.

32 The assumption that Schumpeter is engaged in a methodological attempt to construct a universal social science, a view challenged here in section 4.
} 
and unexpected events are always possible. ${ }^{33}$ In the subsequently omitted seventh and last chapters of the original edition of $T E D$, Schumpeter is in fact particularly clear about the need to adopt a closedsystem framework as the starting point for a scientific investigation of economic development. ${ }^{34}$ As shown once again by da Graça Moura (2003, pp. 288-293), Schumpeter's subsequent methodological stances indicate that he stuck to this view. At the same time, however, Schumpeter sees the social world as an open system, as is easily demonstrated by recalling the meaning he gives to the ideas of economic development (the introduction of innovations and structural changes) and scientific development in social sciences, at least at first sight (grouping and contrasting schools). It is also clear that all this is at variance with his methodological agenda. This is where Schumpeter's contradictions concerning continuity and discontinuity with regard to the development of social sciences take concrete shape. How does he endeavour to cope with these contradictions? As we have seen, Schumpeter interprets the development of the social sciences in VZS through reference both to conflict between schools of thought and to science in the true sense. Radical discontinuities are born out of the former, whereas continuity depends on the latter. There is thus a tension in Schumpeter between the way in which he sees the world (an open system) and the way in which he sees science (a closed system). In $V Z S$, unlike the TED, a stabilising force can therefore be identified in what he calls the Logik der Dinge. ${ }^{35}$ The element of instability can never be eliminated completely, however, and Schumpeter indeed links cyclical development to the fact that scientific method can be rejected under the pressure of a dogmatic perspective (i.e. metaphysics), which always tends to resurface in the social sciences. In other words, there is tension between metaphysics and analytical thinking.

\subsection{Metaphysics and ideology}

This is not all, however. We argue that our perspective can also help to understand Schumpeter's hostility to metaphysics itself. While this point can only be fully understood by taking into account the

\footnotetext{
${ }^{33}$ See da Graça Moura 2002, p. 814 where it is clearly stated: 'That [...] [Schumpeter] conceives of the social world as an open system seems to follow from his views on entrepreneurship and innovation. Entrepreneurship is argued to involve creative idiosyncrasy, and accordingly innovation 'cannot be predicted by applying the ordinary rules of inference form the pre-existing facts' (Schumpeter 1947, p. [150])'.

${ }^{34}$ See Schumpeter 2011[1911], pp. 155-226.

${ }^{35}$ One might interpret the emphasis on the Logik der Dinge as stressing the importance of the material base as opposite to the theoretical superstructure, as one of the referees did. For instance, one might think that the Logik der Dinge imposed itself on mainstream macroeconomic theory after the sub-prime crisis, with the result that its scientific status is now contested. We believe we can say that, unfortunately, the situation has not developed in this direction. Consequently, it would seem that our reading, besides being in line with Schumpeter's texts, is more appropriate to understand the dynamics of the current models of evaluation of scientific work in economics. On this last point, see note 58.
} 
schools of philosophical thought that characterised the German-speaking world in the early 20th century, these schools make up a complex whole that cannot be comprehensively addressed here. It can be noted, however, that a renewal of interest in Kant's transcendental philosophy and above all his theory of knowledge manifested itself in the late 19th and early 20th century, especially in Germany. This phenomenon is known as neo-Kantianism or neo-criticism ${ }^{36}$ and divided into two major schools: the Marburg School led by Herman Cohen and Paul Natorp (in Marburg respectively from 1875 to 1912 and 1885 to 1924), which focused primarily on analysis of the conditions making knowledge possible so as to avoid the metaphysical tendencies of idealism, and the Southwest German School based in the universities of Freiburg and Heidelberg, where Wilhelm Windelband and Heinrich Rickert addressed the foundations of normativity and value judgments (quaestio iuris). All that is really needed here is simply to point out the way in which Schumpeter refers to Kant in VZS. Interestingly enough, the author of the Critique of the Pure Reason (Kritik Der Reinen Vernunft) is quoted nine times and attributed the merit of separating science from metaphysics: 'Only when it has been recognised - as definitively asserted by Kant - that we can only observe the world in general and therefore also the social world through our subjectivity, and furthermore that any objective necessities can only be reflected in the psyche, only then can it be said that the social sciences are getting under way., ${ }^{37}$

\footnotetext{
${ }^{36}$ For a review and a reconstruction of the neo-Kantian position, see for example De Warren, Staiti (eds.) 2015, especially chapters 7, 8 and 11. In fact, at the beginning of 20th century, Kant's philosophy was particularly discussed in the German and Austrian-Hungarian Universities. Eugen Ehrlich published in 1913 the book, which officially marked the emergence of the sociology of law: Grundlegung der Sociologie des Rechts (Fundamental Principles of Sociology of Law). Ehrlich was the only colleague in Czernowitz to be sincerely admired by Schumpeter. Anyone who deals with Schumpeter's discourse on the social sciences cannot but notice a fiery admiration for Eugen Ehrlich's methodological approach, and consequently an implicit distance from the Kantian approach sustained by Hans Kelsen. At the core of Ehrlich's thought is the concept of "living law" (lebendes Recht). The canonical definition of what is meant by living law is usually taken to be Ehrlich's statement that, "[t]he living law is the law which dominates life itself even though it has not been posited in legal propositions. The source of our knowledge of this law is, first, the modern legal document; secondly, direct observation of life, of commerce, of customs and usages and of all associations, not only those that the law has recognised but also of those that it has overlooked and passed by, indeed even of those that it has disapproved' (see Ziegert, 2017, p. xxxiv). In line with this definition, the scientific nature of legal science should be characterised by a reasoning that proceeds from concrete situations to abstract principles: the centre of gravity of legal development lies not in legislation, nor in juristic science, nor in judicial decision, but in society itself. Vice versa following Kelsen's argument the scientific nature of legal science is based on a pure theory of law in a sense analogous to that in Kant's thought. The "pure part" of legal science consists of a framework of fundamental concepts. Then, in an empirical part of legal science, this framework would be applied to empirical material so as to understand that material as "law" (see Nelken, 2008). In VZS Schumpeter accepts Ehrlich's approach: not only the centre of gravity of legal development but also the centre of gravity of social sciences development lies in society itself.

37 Original: 'Erst wenn man erkannt hat - wie definitiv von Kant verkündet wurde -, daß jeder nur von seiner Subjektivität aus in die Welt überhaupt und also auch in die soziale Welt blicken kann, und ferner, daß sich alle eventuellen objektiven Notwendigkeiten nur in der Psyche spiegeln können, kann man sagen, daß die Sozialwissenschaften flott geworden sind'. Schumpeter 2014[1915], p. 27.
} 
Schumpeter confines Kant's critical philosophy to the horizon of a "theory of knowledge" and ignores his intention to develop metaphysics as the science of the limits of reason, ${ }^{38}$ appearing rather to look forward to the attitude expressed in the Vienna Circle Manifesto (1929): 'The metaphysician and the theologian believe, thereby misunderstanding themselves, that their statements say something, or that they denote a state of affairs. Analysis, however, shows that these statements say nothing but merely express a certain mood and spirit. ${ }^{39}$ And this may be the reason why Kant's "Copernican revolution" and the philosophical problems he tried to solve in general, above all the attempt to eliminate the contrast between deductive apriorism and experience, are of interest to Schumpeter almost exclusively for their effects on the separation between science and metaphysics.

Thorough consideration of the role of metaphysics in the reflections developed by Schumpeter in Czernowitz is also useful in order to compare VZS with Economic Doctrine and Method and the History of Economic Analysis. Is VZS only 'a brief outline of what first became [...] [Economic Doctrine and Method] and finally the History of Economic Analysis', as Elizabeth Boody Schumpeter wrote in the Editor's Introduction ${ }^{40}$ to the History of Economic Analysis, or should it be read as a complement to Economic Doctrine and Method and perhaps the History?

While it is possible in our view to detect a certain complementarity between the Czernowitz essay and Economic Doctrine and Method, it must be immediately added that this is not complete or perfect. The relationship is analogous to that between a picture frame (VZS) and a detail (Economic Doctrine and Method) of the painting it contains. ${ }^{41} \mathrm{VZS}$ is to be regarded as a reflection on the understanding of science in sociological terms, whose primary result is an evolutionary theory capable of contextualising the development of all the social sciences, ${ }^{42}$ whereas Economic Doctrine and Method specifically

\footnotetext{
${ }^{38}$ Significantly enough, the "popular exposition" of the Critique of the Pure Reason is entitled by Kant Prolegomena to any Future Metaphysics that Will Be Able to Present Itself as a Science (Prolegomena zu einer jeden künftigen Metaphysik, die als Wissenschaft wird auftreten können) - emphasis added in both cases. To our knowledge, the best contribution on this subject is Gagliardi 1998. For a similar view of Schumpeter's reference to Kant, see Kesting 2008 (esp. pp. 83-84), an analysis of the Wesen und der Hauptinhalt.

39 Quoted from The Scientific Conception of the World: The Vienna Circle, available at http://evidencebasedcryonics.org/pdfs/viennacircle.pdf.

${ }^{40}$ See Boody Schumpeter 2006[1954], p. XXXII. As already mentioned in paragraph 1, in actual fact, the Editor's Introduction dates from July 1952.

${ }^{41}$ Something similar is also recognised by Shionoya, albeit from a different perspective: '[Vergangenheit und Zukunft der Sozialwissenschaften] is an expansion of his farewell lecture at the University of Czernowitz in 1911. It can be argued that Schumpeter's early studies on economic thought consisted of Epochen der Dogmen- und Methodengeschichte [...] and the 1915 book; the former deals with economic theory and the latter with the social sciences, including sociology.' Shionoya 2005, chapter 9, p. $177 \mathrm{n}$.

42 A different assertion is made in Kesting 2005, p. 77: 'Schumpeter himself never elaborated his ideas about scientific development in a systematic way. He did not devote any single essay or even chapter to this topic' (emphasis added). The
} 
addresses the evolution of economics. In doing so, it attempts, among other things, to meet the requirements of the series of book in which it was published. ${ }^{43}$ Real similarity between the two works can be found only at the end of Economic Doctrine and Method, where Schumpeter writes:

The vehemence of the controversies about methods and doctrines in our discipline often seems to interrupt the continuity of development. This vehemence can be explained partly by the inherent character of economics and the political interest which people take in economic theses that are either really or allegedly economic; partly it results from the fact that determined scientific work in this field is of comparatively recent date. Nevertheless it is surprising how comparatively little the controversy of the day influenced the course of quiet studies at the time.

If we look through the veil of the arguments employed in the struggle we see much less of the contrasts which are usually formulated on principle with such acerbity. We see that these contrasts are not always irreconcilable materially and that the different schools do not easily overcome each other to the point of annihilation. (Schumpeter 1954[1914], pp. 200-201)

This is quite clearly akin to what can be found in $V Z S$, where Schumpeter speaks about the "logic of things" (Logik der Dinge):

Like the factors of discontinuity, those of continuity will also go on operating. The very elements that justify the prediction that the factors of discontinuity will become weaker will, however, increase the strength of the "logic of things". [...] Advances and setbacks will become less violent, the area of methodological and factual common ground [communis opinio] larger, the clouds of dust less thick and the battle cries less strident [...]. ${ }^{44}$ (Schumpeter 2014[1915], p. 107 ; p. 108)

The same line of reasoning is even more direct in the work devoted solely to economics:

author appears to contradict himself on p. 80: 'After the publication of Vergangenheit und Zukunft der Sozialwissenschaften [...] Schumpeter did not deal seriously with the problem of scientific development for many years.' In our opinion, the point is that Kesting regards Wesen und der Hauptinhalt as the work really essential to an understanding of Schumpeter's position and is, as a result, unable to contextualise Vergangenheit und Zukunft satisfactorily. See note 49.

43 Something similar is also recognised by Kesting: 'Epochen der Dogmen- und Methodengeschichte is part of the monumental Grundriß der Sozialokonomik, a handbook, the publication of which was dominated by members of the Historical School. The fact that Schumpeter was entrusted by Max Weber to write the chapter on the history of economics [...] demonstrates the high reputation Schumpeter already enjoyed amongst the members of the Historical School [...]. However, the initiative for such an inquiry did not come from Schumpeter himself [...]' Kesting 2006, p. 407 n.

44 Original: 'Wie die Gründe der Diskontinuität, so werden auch die der Kontinuität fortwirken. Aber eben die Momente, die die Prognose rechtfertigen, daß die Gründe der Diskontinuität immer schwächer wirken werden, werden die Macht der „Logik der Dinge“ fördern. [...] Immer weniger heftig werden Vorwärtsbewegungen und Rückschläge werden, immer größer das Gebiet methodologischer und sachlicher Communis opinio, immer weniger dicht die Staubwolken, weniger laut die Schlagworte [...].' 
Phases of development cannot be passed over in the case of an organic body any more than in the case of political, social or scientific bodies. Nevertheless the misdirection of energy will abate as time goes on and then it will be easier to survey the basic outlines of the work done in the field of social science during the last 150 years and to discover its underlying unity. (Schumpeter 1954[1914], p. 201)

Let us now consider the History. The first point to be noted is the difference in approach. In other words, the framework is different. ${ }^{45}$ Even though Schumpeter continues to display a marked aversion for metaphysics, the cornerstone of the History in methodological terms is the concept of "vision" and the major problem it addresses is accordingly ideology.

We contend that the references to metaphysics found in the 1915 text do not have the same function as those to ideology in the History. In VZS metaphysics is assigned three characteristics: 1) it slows down scientific work; 2) it is completely useless; 3) its effects decrease parallel to (and because of) scientific development. Even though ideology, which Schumpeter addresses in his "historical methodological phase", ${ }^{46}$ also slows down scientific progress, scientists cannot work properly without it. Ideology is indeed a part of the vision that Schumpeter ultimately came to see as essential to the very existence of science.

This point can be shown by means of the following philologically questionable but logically legitimate operation: crossbreeding some concepts and quotes from Science and Ideology with others from the History. In fact, the clearest definition of ideology to be found in Schumpeter's writings is the one contained in his 1949 article, where ideologies are 'truthful statements about what a man thinks he sees', 'superstructures' erected on reality. These superstructures constitutively depend on the underlying, objective social structure but tend to reflect it in a distorted way (Schumpeter 1949, p. 349). Schumpeter sees ideological bias as a danger for economic science, however, albeit not of course the only one.

It is also necessary to take into account, as Schumpeter did in the History, the possible distortion of facts or procedural rules on the part of advocates as well as value judgments, which often reveal an ideology but do not coincide with it. ${ }^{47}$ Therefore, the pursuit throughout the History of an evolutionary reading of economics - which is almost reduced to a toolbox - through purification from ideology finds

\footnotetext{
${ }^{45}$ See De Vecchi 1995, quoted in note 50 here below. Something similar has been recognised also by Kesting, albeit from a different standpoint: 'The consideration of its social dimension is probably the most important extension of Schumpeter's understanding of scientific development in his later as opposed to his earlier work'. See Kesting 2005, p. 82.

${ }^{46}$ According to Kesting's classification. See Kesting 2006, pp. 388 and 401-404.

${ }^{47}$ On this point, see Schumpeter 2006[1954], p. 35.
} 
precise confirmation in the above-mentioned Science and Ideology. Consider for example the unfinished fourth chapter of the History:

It is true that in economics, and still more in other social sciences, this sphere of the strictly provable is limited in that there are always fringe ends of things that are matters of personal experience and impression from which it is practically impossible to drive ideology, or for that matter conscious dishonesty, completely. The comfort we may take from our argument is therefore never complete. But it does cover most of the ground in the sense of narrowing the sphere of ideologically vitiated propositions considerably, that is, of narrowing it down and of making it always possible to locate the spots in which it may be active. (Schumpeter 2006[1954], p. 40)

If we now complete it with the closing lines of the 1949 article, the issue of ideology as an unavoidable element is adequately clarified:

That prescientific cognitive act which is the source of our ideologies is also the prerequisite of our scientific work. No new departure in any science is possible without it. Through it we acquire new material for our scientific endeavours and something to formulate, to defend, to attack. Our stock of facts and tools grows and rejuvenates itself in the process. And so, though we proceed slowly because of our ideologies, we might not proceed at all without them. (Schumpeter 1949, p. 359)

To summarise, the above-mentioned remark by Elisabeth Boody Schumpeter fostered the idea that in Schumpeter's work, investigation of the social sciences is nothing but a preamble to reflection on economic theory. The argument put forward in this section suggests instead that the reality is far more complex.

\section{A unicum in Schumpeter's writings?}

In order to reconnect the different strands of our argument, it appears useful to recall that the most recent works by historians of economic thought assign an important role to $V Z S$ in their interpretations of Schumpeter's methodology. We refer in particular to the works of Kesting and Shionoya, whose interpretation of the essay appears, however, to clash with the reading developed above. 
Kesting (2008) describes $V Z S$ as perhaps 'the least known of Schumpeter's major works'48 and goes on to focus exclusively on Wesen und der Hauptinhalt.

Kesting (2006) seeks to develop a periodisation of Schumpeter's thought based on research subjects and methodological approaches. What is shown is essentially that they change within his work. Despite sympathy with his vision, which emphasises discontinuity rather than continuity in Schumpeter's trajectory, it must be pointed out that $V Z S$ does not fit in very well, as the author himself admits. ${ }^{49} \mathrm{VZS}$ should perhaps be regarded as a unicum in Schumpeter's work. ${ }^{50}$

Kesting (2005) tends to read VZS in the same light as Das Wesen und der Hauptinhalt der theoretischen Nationalökonomie (1908). In his view, both works provide evidence of a research programme to be found in all of Schumpeter's work, albeit never fully expressed. This programme is for a theory to understand of the process of science development. As pointed out above, there is certainly an attempt to define the logic of scientific development in the Czernowitz essay. The differences between VZS and the book of 1908 are, however, extremely significant. In Wesen und der Hauptinhalt, Schumpeter not only focuses exclusively on economic theory (as he was to do in Economic Doctrine and Method) but also stresses its independence with respect to other disciplines. Nevertheless, he also argues that 'the relations of pure economics with other disciplines, which occupy so much space in prefaces and occasional utterances, have very little or nothing to tell us. In the interests of clarity, it is imperative to point out their triviality and jettison this dead weight.' ${ }^{51}$ (Schumpeter 1908, p. 553). It should, however, be pointed out that Schumpeter already appears aware in 1908 that some phenomena affecting economic reality cannot be analysed in the static context of Wesen und der Hauptinhalt. It is Schumpeter's interest in dynamics that prompted him to write TED, his most innovative work, in 1911. As suggested here, this also led him to a radical reconsideration of

\footnotetext{
${ }^{48}$ Kesting 2008, p. 78.

${ }^{49}$ See Kesting 2006, p. 407 n, where he admits that, with respect to the "theoretical methodological phase" of his classification of Schumpeter's evolution, 'the publication of Vergangenheit und Zukunft der Sozialwissenschaften, which can be characterized as a programmatic work, was not initiated [unlike Economic Doctrine and Method] by another person and is therefore a little out of place' (emphasis added).

${ }^{50}$ The point is very complex and can only be outlined here. The essay of 1915 can in fact be regarded as one of the most mature achievements of a "worldview" (Geistesrichtung) concerning the vision of the social sciences in the Mitteleuropean world of the belle époque, then brought to a whose violent and dramatic end by WWI. As De Vecchi argues, 'Schumpeter's Austrian period began and ended the creative part of his life. Later on he will revise his ideas in the light of other historical experiences, in other settings, in connection with other scholars and using other methods of analysis' (De Vecchi 1995, p. xiii).

51 Original: 'Beziehungen der reinen Ökonomie zu anderen Disziplinen, die sich in Vorworten und gelegentlichen Äußerungen so breit machen, haben uns nur wenig zu geben - oder nichts. Im Interesse der Klarheit ist es geboten, ihre Nichtigkeit zu betonen und diesen Ballast über Bord zu werfen'.
} 
the relations between economic theory and the other social sciences. In this respect, $V Z S$ offers important evidence of such a change in perspective ${ }^{52}$ and can perhaps for this reason be seen as a unicum in Schumpeter's work. It is in fact the first and only time that he uses a framework similar to the one developed in TED to examine the evolution of economic theory and the social sciences in general. ${ }^{53}$

Shionoya claims in several works $(1990 ; 1997 ; 2004 ; 2005 ; 2009)$ that Schumpeter pursues the ambitious goal of developing a "comprehensive sociology" or a "universal social science". In order to show that 'Soziologisierung [i.e. sociologising] for a reunification of the social sciences is the basic framework within which to understand Schumpeter's work' (Shionoya 2005, p. 163), he quotes the following passage from VZS in the ninth chapter of his The Soul of the German Historical School:

The substance of the new epoch is revealed by the tendency to understand as many things around us as possible-i.e., law, religion, morality, art, politics, economy, even logic and psychology-from sociology. The analysis of cultural phenomena is the lighthouse that the social fleet of different courses is headed for. And an epoch similar to the eighteenth century is approaching. ${ }^{54}$ (Schumpeter 2014[1915], pp. 132-133, as quoted in Shionoya 2005, p. 163)

On the basis of a closer reading of $V Z S$, we instead regard it as possible to argue that Schumpeter is not interested in developing a universal social science aimed at unifying the different fields of knowledge that he examines, not least because he assumes the plurality of social science as an inescapable fact:

If social science were an organic whole whose individual parts interlock in a unified project, our task would be easier than it is [...]. But social science is as little an "architectural" whole as science is in general. It is rather a conglomeratation of individual elements that often have

\footnotetext{
52 See note 17. It shows, for example, Schumpeter's change of mind about the Historical School.

53 The framework used in the History is different, as we have seen.

${ }^{54}$ Original: 'Es ist eine Epoche konstruktiver Lust, keine kritisch-sammelnd gestimmte, darüber kann kein Zweifel sein. Ihr Inhalt ist durch jene Strömung gegeben, die ich früher als „Soziologisieren“ bezeichnet habe, jene Tendenz nach dem Begreifen von möglichst Vielem an uns, von Recht, Religion, Moral, Kunst, Politik, Wirtschaft, ja selbst Logik und psychischen Erscheinungen, aus der Soziologie heraus. Die Analyse des Kultur-phänomens ist der Leuchtturm, auf den ganze Flotten verschiedensten Charakters auf den verschiedensten Kursen zusteuern. Und eine Epoche, die dem 18. Jahrhundert in Vielem gleicht, kündigt sich an.' Shionoya's translation in fact appears questionable on a careful reading of the original, which can be translated more literally as: 'It is unquestionably an era eager to construct rather than criticise and one characterised by what I refer to above as "sociologising", a drive to understand as much as possible - law, religion, morality, art, politics and the economy, even logic and psychological phenomena - in sociological terms. The analysis of cultural phenomena is the lighthouse on which entire fleets of all kinds and very different routes converge. And an era that resembles the 18 th century in many respects lies in store.'
} 
precious little to do with one another [...]. For this reason, there is not one social science in the end but only social sciences whose orbits frequently intersect. ${ }^{55}$ (Schumpeter 2014[1915], pp. 34)

Something similar is also recognised by Swedberg, albeit from a different perspective. ${ }^{56}$ In fact (see Swedberg 1989, p. 511) he clearly states that '[w]hat [...] [social sciences] studied was mainly an accidental result of history; and the lines between the social sciences were anything but sharp. That several social sciences studied the same problem was according to Schumpeter quite common'. It is interesting to note that, to further specify his stance according to which, for Schumpeter, there is no such thing as a single or universal social science, Swedberg quotes one of the initial paragraphs of VZS in which it is written: 'There basically does not exist one single social science but several social sciences whose sphere of interest intercesct' (Schumpeter 2014[1915], p. 4 as quoted in Swedberg 1989, p. 511).

Indeed, Schumpeter's view of the "sociologising" (Soziologisierung) of the social sciences, as expressed in the last part of the Czernowitz essay, does not mean that he is striving for a "comprehensive sociology" in Shionoya's terms, that is to say for 'an approach to social phenomena as a whole which is supposed to be a synthesis of interaction between every single area and all others in a society' (Shionoya 2004, p. 5). In our view, Shionoya misunderstands the meaning of Soziologisierung, as the word does not imply a process of convergence of different disciplines or a sort of supremacy of sociology over other sciences. As Schumpeter himself writes, for example, about law:

We seek to attain an understanding of juridical phenomena through knowledge of the nature of society on the one hand and of how our thinking and feeling operate on the other. We seek, as it were, to sociologise and psychologise law, to understand juridical propositions, juridical situations and the application of law as social phenomena in scientific, theoretical and analytical terms. ${ }^{57}$ (Schumpeter 2014[1915], pp. 82-83)

55 Original: 'Wäre die Sozialwissenschaft ein organisches Ganzes, dessen einzelne Teile sich einem einheitlichen Plan einfügen würden, so wäre unsere Aufgabe leichter als sie ist [...]. Aber die Sozialwissenschaft ist so wenig ein „architektonisches“ Ganzes, wie die Wissenschaft überhaupt. Sie ist vielmehr ein Konglomerat von einzelnen Bausteinen, die oft herzlich wenig aneinanderpassen wollen [...]. Und deshalb gibt es im Grunde keine Sozialwissenschaft, sondern nur Sozialwissenschaften, deren Kreise sich vielfach schneiden.'

${ }^{56}$ The subject of Swedberg's paper is Schumpeter's economic sociology. In developing his argument, he highlights both the points of contact between economics and economic sociology and the fact that Schumpeter was clearly against merging the two too closely, for cross-fertilisation might easily result in cross-sterilisation.

${ }^{57}$ Original: 'Man will vordringen zum Verständnis des Rechtsphänomens aus dem Wesen der Gesellschaft heraus einerseits und aus der Art und Weise wie unser Denken und Fühlen arbeitet andrerseits: Man will Rechtswissenschaft, wenn ich so sagen darf, soziologisieren und psychologisieren; man will den Rechtssatz, den Rechtszustand, die Rechtsanwendung als soziale Phänomene wissenschaftlich - analytisch - theoretisch verstehen.' 
We therefore suggest that "sociologising" (Soziologisierung) indicates the scientific method characteristic of disciplines whose objects of analysis are social phenomena. Even though Schumpeter regards the scientific method as always the same, as shown above, different research programmes are pertinent to different disciplines in sociological terms.

\section{Conclusions}

The purpose of this paper is to shed new light on one item of Schumpeter's production, namely an essay that he wrote during a profoundly significant stage of his intellectual trajectory and to which he devoted a great deal of time. It is important to stress once again that the aim of his text is not to establish a "comprehensive sociology" but rather to put forward a historically determined interpretative framework for the evolution of the social sciences.

Within this framework, Schumpeter reconsiders some crucial moments in the history of the social sciences in Europe. He does so in a particular time and place. His perspective is that of a scholar of the social sciences educated when the Austro-Hungarian Empire was at its peak. The period in which VZS was conceived and written coincides with the years immediately before WWI. As is well known, this tragic event brought about considerable changes in the global role of the social sciences as well as decreasing the political and cultural centrality of the Mitteleuropa in which Schumpeter grew up. Moreover, the Great War produced a fundamental change of direction in his research.

It is argued here that the essay cannot be regarded as merely looking forward to the History but neither can it be regarded as perfectly in line with Economic Doctrine and Method. On the contrary, as shown above, VZS is in a certain sense a unicum in the context of Schumpeter's work. To substantiate this claim, a comparative examination is carried out of a relevant section of the most recent literature, taking carefully into account scholars (Kesting and Shionoya) who have influenced the international debate by correctly stressing the importance Schumpeter attached not only to economics but also to the other social sciences. It emerges that these authors have partially overlooked some fundamental elements that fully emerge on consideration of $V Z S$ in greater depth.

In actual fact, both the absence of an English translation of the original German and the difficulty of ascertaining the specific meaning of some German expressions in this particular essay, where Schumpeter uses very complex and academic language - deliberately in line with the current rhetoric can help to explain why some major misunderstandings have arisen. The interpretation developed here 
makes it possible to clarify both the role played by metaphysics within the framework employed by Schumpeter in VZS and the contextual meaning to be attributed to the idea of Soziologisierung.

Finally, we believe that careful consideration of $V Z S$ could open up new horizons of research in Schumpeterian studies and even provide new stimuli for recent debate on subjects such as the criteria of evaluation in the social sciences and the role they play in decisions on the kind of research to be funded. Endogenous shocks, represented today above all by the disruptive role of economic policy preferences, are in fact capable of influencing the academic community of social scientists and the future development and structure of the social sciences. ${ }^{58}$

It is the latter subject in particular that will be addressed in our future research.

\section{Bibliography}

Blaug, M. 2009[1980]. The Methodology of Economics, or How Economists Explain, Cambridge (UK), Cambrigde University Press.

Boody Schumpeter, E. 2006[1954]. Editor's Introduction, pp. XXX-XXXVII, in Schumpeter, J. A., History of Economic Analysis, op. cit.

da Graça Moura, M. 2002. Metatheory as the key to understanding: Schumpeter after Shionoya, Cambridge Journal of Economics, vol. 26, no. 6, 805-821.

da Graça Moura, M. 2003. Schumpeter on the integration of theory and history, European Journal of History of Economic Thought, vol. 10, no. 2, 279-301.

da Graça Moura, M. 2015. Schumpeter's conceptions of process and order, Cambridge Journal of Economics, vol. 39, no. 4, 1129-1148.

De Gennaro, I. (ed.) 2012. Value. Sources and Readings on a Key Concept of the Globalized World, Leiden (ND), Boston (MA), Brill.

De Vecchi, N. 1995. Entrepreneurs, Institutions and Economic Change: The Economic Thought of Joseph Schumpeter (1905-1925), Brookfield (VT), Edward Elgar.

De Warren, N., Staiti A. (eds.) 2015. New Aprroaches to Neo-Kantianism, Cambridge (UK), Cambridge University Press.

\footnotetext{
${ }^{58}$ An example is provided by the procedures for grading both teaching and scientific research, which in many cases involve the application of a model of evaluation that does not consider the content of the scientific work but simply awards points. In the case of teaching, this ranking is based on assessments given by students before taking their exams. In the case of research, what counts is the supposed "prestige" of the place of publication, which depends in turn on the tables drawn up by some international publishers and taken up with few adjustments by the evaluation committees set up by ministries of eduction. The scientific journals characterised by a critical approach to the social sciences occupy the lowest positions in these tables (see Lee, 2006). The careers of researchers but also an ever-larger proportion of the research funding depend on these criteria. The model tends to produce rankings of scholars based upon their comparative evaluation in terms of modular performance, and research activities that are not performing well in modular terms appear inadequate or outdated. See De Gennaro (ed.), 2012.
} 
Gagliardi, F. 1998. Kant e il problema dell'ontologia (Kant and the Problem of Ontology), Gaeta, Bibliotheca.

Haberler, G. 1950. Joseph Alois Schumpeter (1883-1950), Quarterly Journal of Economics, vol. LXIV, no. 3, 333-372.

Kesting, P. 2005. Vision, revolution, and classical situation: Schumpeter's theory of scientific development, History of Economic Review, vol. 41, no. 1, 77-97.

Kesting, P. 2006. The interdependence between economic analysis and methodology in the work of Joseph A. Schumpeter, European Journal of History of Economic Thought, vol. 13, no. 3, 387-410.

Kesting, P. 2008. One Hundred Years From Today. Joseph A. Schumpeter: Das Wesen und der Hauptinhalt der theoretischen National ökonomie, History of Economic Review, vol. 48, no. 3, 7891.

Kreps, D. M. 1990. A Course in Microeconomic Theory, Princeton (NJ), Princeton University Press.

Lee, F. 2006. The Ranking Game, Class and Scholarship in American Mainstream Economics, Australasian Journal of Economcis Education, vol. 3, no. 1-2, 1-41.

Leontief, W. 1950. Joseph A. Schumpeter (1883-1950), Econometrica, vol. 18, no. 2, 103-110.

Machlup, F. 1951. Schumpeter's Economic Methodology, Review of Economics and Statistics, vol. 33, no. 2, 145-151.

McCraw, T. M. 2007. Prophet of Innovation: Joseph Schumpeter and Creative Destruction, Cambridge (MA), Harvard University Press.

Nelken, D. 2008. Eugen Ehrlich, Living Law and Plural Legalities, Theoretical Inquiries in Law, vol. 9, no. 2, 443-471.

Popper, K. 2005[1935]. The Logic of Scientific Discovery, London (UK) and New York (NY), Routledge.

Schumpeter, J. A. 1908. Das Wesen und der Hauptinhalt der theoretischen Nationalökonomie, Leipzig (DE), Duncker und Humblot.

Schumpeter, J. A. 2011[1911]. The Fundamental Phenomenon of Economic Development, pp. 79-154 in Becker M. C., Knudsen T. and Swedberg R. (eds), The Entrepreneur. Classic Texts by Joseph A. Schumpeter, Stanford (CA), Stanford University Press.

Schumpeter, J. A. 2011[1911]. The View of Economy as a Whole, pp. 155-226 in Becker M. C., Knudsen T. and Swedberg R. (eds), The Entrepreneur. Classic Texts by Joseph A. Schumpeter, Stanford (CA), Stanford University Press.

Schumpeter, J. A. 1954[1914]. Economic Doctrine and Method. An Historical Sketch, New York, Oxford University Press. Original edition: Epochen der Dogmen- und Methodengeschichte, pp. 19124 in AA.VV., Grundriss der Sozialökonomik. I. Abteilung, Wirtschaft und Wirtschaftswissenschaft, Tübingen (DE), J. C. B. Mohr.

Schumpeter, J. A. 2014[1915]. Vergangenheit und Zukunft der Sozialwissenschaften, San Bernardino (CA), Reprints from the collection of University of Michigan Library. Original edition: München und Leipzig (DE), Duncker \& Humblot. 
Schumpeter, J. A. 1961[1926]. The Theory of Economic Development, Cambridge (MA), Harvard University Press. English Translation of Theorie der wirtschaftlichen Entwicklung, $2^{\text {nd }}$ edition, München und Leipzig (DE), Duncker \& Humblot.

Schumpeter, J. A. 1947. The Creative Response in Economic History, The Journal of Economic History, vol. 7, no. 2, 149-159.

Schumpeter, J. A. 1949. Science and Ideology, The American Economic Review, vol. 39, no. 2, 346359.

Schumpeter, J. A. 2006[1954]. History of Economic Analysis, Taylor \& Francis e-Library. Original edition: New York (NY), Oxford University Press.

Shionoya, Y. 1990. The Origin of the Schumpeterian Research Program: A Chapter Omitted from Schumpeter's Theory of Economic Development, Journal of Institutional and Theoretical Economics, vol. 146, no. 2, 314-327

Shionoya, Y. 1991. Schumpeter on Schmoller and Weber: A Methodomogy of Economic Sociology, History of Political Economy, vol. 23, no. 2, 193-219.

Shionoya, Y. 1997. Schumpeter and the Idea of Social Science: A Metatheoretical Study, Cambridge (UK), Cambridge University Press.

Shionoya, Y. 2004. Scope and Method of Schumpeter's Universal Social Science: Economic Sociology, Instrumentalism, and Rhetoric, Journal of History of Economic Thought, vol. 26, no. 3, $331-347$.

Shionoya, Y. 2005. Schumpeter on the Relationship between Economics and Sociology from the Perspective of Doctrinal History', pp. 163-178, in Shionoya, Y., The Soul of the German Historical School, New York (NY), Springer.

Shionoya, Y. 2009. The History of Economics as Economics, European Journal of History of Economic Thought, vol. 16, no. 4, 575-597.

Swedberg, R. 1989. Joseph A. Schumpeter and the Tradition of Economic Sociology, Journal of Institutional and Theoretical Economics, vol. 145, no. 3, 508-524.

Swedberg, R. 1991. Joseph A. Schumpeter. His Life and Work, Princeton (NJ), Princeton University Press.

Zanini, A. 2008. Economic Philosophy. Economic Foundations and Political Categories, Oxford (UK), Bern (CH), Berlin (DE), Bruxelles (B), Frankfurt am Main (DE), New York (NY), Wien (A), Peter Lang.

Ziegert, K. A. 2017. Introduction, pp. xix-1, in Ehrlich, E., Fundamental Principles of the Sociology of Law, Oxon (UK) and New York (NY), Routledge. 